\title{
DOI: https://doi.org/10.24297/jssr.v16i.8789
}

\section{The Transition From Classroom to Zoom and How it Has Changed Education}

\author{
Adam Stefanile \\ Teachers College, Columbia University, Department of Mathematics, Science, \& Technology \\ 525 West 120th Street New York, NY 10027 \\ as4961@tc.columbia.edu \\ Running head: Online Learning and the COVID-19 Pandemic
}

\begin{abstract}
In 2020, millions of students, educators, and academic faculty (and others in the world of government, business, etc. worldwide) became aware of greater emphasis for distance teaching and learning (DTL) and communication, especially given the demands being made due to the COVID-19 pandemic. More particularly, some innovative technologies have especially been designed to bring a new coherence to the integral intersection of the teaching and learning dimensions of education, especially when focused on student-centered teaching and learning While there may have been a grace period for educators to adjust to this paradigm shift, the online educational resources and interactive platforms for teaching science, technology, engineering, and mathematics (STEM) have made more immediate applications possible, especially given the challenges of teaching during a pandemic The availability of technology in all academic settings, particularly STEM, has enabled educators to implement a range of diverse pedagogical approaches to engage their students more effectively in STEM learning. However, some educators lack the pedagogical skills and/or strategies needed to effectively transition to virtual/teaching online STEM topics and/or classes. The purpose of this article is to highlight the effectiveness of DTL learning by utilizing interactive websites and effectively integrating them into STEM classrooms.
\end{abstract}

Keywords: STEM, distance teaching and learning, COVID-19 pandemic

\section{Introduction}

Since the tragedy of the Coronavirus Disease 2019 (COVID-19), all aspects of human life have been affected, especially education. According to UNESCO, over 900 million learners have been affected by the COVID-19 pandemic (including 1,184,126,508 affected learners in 143 country-wide closures as of May 2020) causing closures of educational institutions worldwide (Fig 1). In the Americas, the U. S. A. particularly, is largely the only nation with localized closings, while the preponderance of other nations has country-wide closings. This is also true of Africa, while Europe and Asian countries show a mixture of policies, including widely distributed localized closings and some country-wide closings, but only a few that are fully open. Australia has adopted a policy of localized closings.

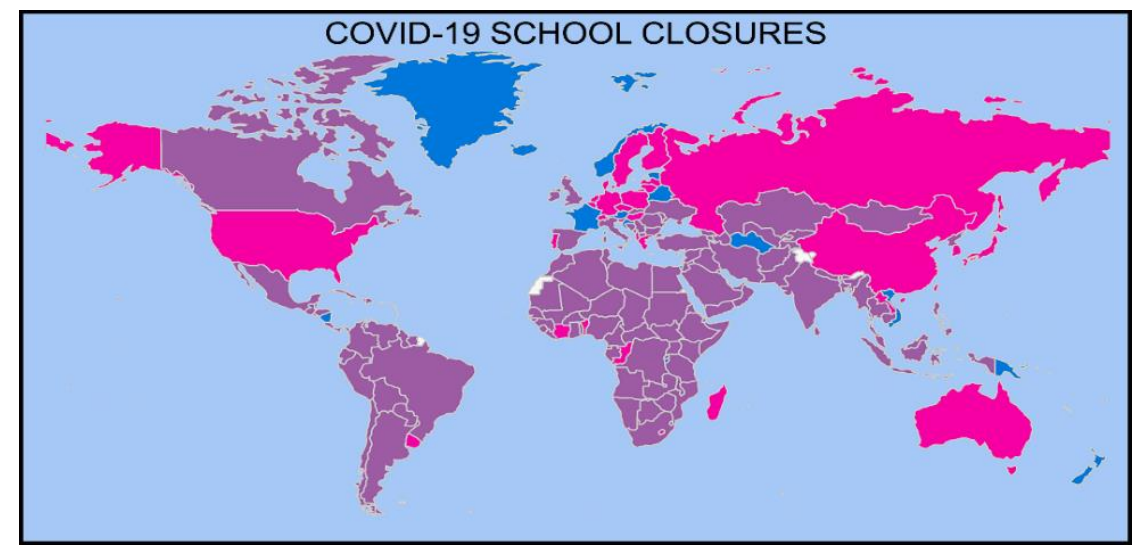

Fig.1: Global map of COVID-19 school closures. Color code: Pink (localized closings), Purple (Country-wide closings), Blue (open). Adapted from UNESCO Global Education Coalition (https://en.unesco.org/covid19/educationresponse) 
Zoom, a video and audio digital tool used primarily for collaborative conferences much like Skype, has and continues to transform how educators interact with and teach their students. Prior to the ubiquity of Zoom, most undergraduate schools used commercially available software to facilitate interaction of educators with their students, such as Canvas, Moodle, and Blackboard. However, many six to twelfth grade schools used Pearson, ClassDojo, Kahoot, and Haiku. Although, many of these educational software programs are beneficial and engaging and provide benefits for more effective learning, most of the commercial educational software have been developed for traditional learning environments. Consequently, the vast potential of these innovations can be lost as teachers upload educational content, images, diagrams, videos, and worksheets; with the result that minimal interaction or DTL occurs. Transforming content knowledge to be more relevant to students may be challenging because of the diverse learning styles that students may present, and the need to be adequately aware of and properly address the prior content knowledge that students may or may not have acquired (Ryan \& Poole, 2019). The challenging issues are typically not the design of the educational software, that often is intended to be richly interactive, rather much of the lost opportunity is due to lack of implementing available interactive websites into daily classroom practices. This insufficient integration of well-designed, interactive learning materials within classroom teaching and learning, further makes DTL difficult for many educators. Faced with the challenges of the current 2020 pandemic, learning environments are of necessity, if not opportunity, geared to distance/virtual learning. Moreover, the face-to-face formats available with some of these DTL options (such as Zoom, Skype, etc.) that have emerged and are accessible worldwide is without a doubt, as many educators have experienced, overwhelming in all subject matter domains.

This article, presenting a viewpoint with professional guidance for STEM educators, is based on a review of the literature. To obtain a reasonably balanced and representative survey of the literature on this topic, the methodology included an online search using the following keywords: Online learning, distant learning, COVID19 and education. In addition, an online search was used for suitable tabular data and figures to supplement the text, particularly with respect to the impact of COVID-19 and current trends in use of online learning; this included keywords such as trends in online learning, school closings and COVID-19, and related topics. A major challenge or problem that most educators, students, and parents are facing is transitioning and acclimating themselves to the use of DTL, while keeping the experience of learning rigorous. Moreover, during such a time, both educators and students should be developing interdisciplinary skills to increase their learning trajectories during the pandemic.

\section{Transition from Classroom to Zoom}

Since the beginning of the millennium, computer-based learning (CBL) has increasingly been used to support STEM classrooms for developing student-centered and collaborative learning, accessing data, and to develop interdisciplinary STEM skills and strategies (Freeman et al., 2014; Holmlund, Lesseig, \& Slavit, 2018). As the COVID-19 pandemic has, and continues to be, one of the greatest challenges that the education system has ever faced (Nicola et al., 2020; Sahu, 2020), students and parents are anxious and uncertain as to when school will resume back to normality. Yet, many educators have been remarkable in implementing their lessons and providing online learning resources and videos to supplement formal learning and instruction (Major, 2020). The transition from formal education to implementing the Zoom platform has been a learning curve and to some extent, frustrating to utilize for many educators and students. The social aspect of learning has been disconnected from student-life; curricula and lesson planning, assessment, and other pedagogical skills and strategies have been overwhelming for educators; and parents have been sitting along-side K-12 students to monitor and assist with their progress. The impact of the long-term use of Zoom has yet to be seen, however, Agarwal and Kaushik, (2020) indicated there were minimal factors that hindered learning including: the number of students that were able to participate at a given time, length of the Zoom session, and technical faults during the conduct of Zoom session.

\section{Distance Teaching and Learning}

Students' sense of socializing and learning at school is a major factor in modern theories of academic learning, motivation, and engagement (Stipek, 2002). Since educators must improvise their pedagogical strategies in a 
virtual environment to effectively communicate with learners and promote their construction of content knowledge as well as any other particularities that arise in the classroom including, class grades, curriculum, and the various interrelations, i.e. between the teacher and their students; it would be in the best interest of educators and learners to be able to transition promptly from traditional classroom learning to DTL. Educators must design their courses to encourage effective DTL rather than assigning pointless online searching for terms and/or STEM information. Exposing students to CBL and interactive STEM websites will significantly enhance overall student learning and allow for the best utilization of simulation resources (McKimm, Jollie, \& Cantillon, 2003). "While distance education has been happening over the past 3-4 decades, the evolution of online learning has been growing rapidly in the higher education fields" (Barrett, 2010, p. 19). DTL is an alternative means of learning in which teachers can educate their students virtually. This field has its origins from prior innovative educational practices, that extended beyond typical classroom educational experiences, such as independent study, studentcentered learning, project-based learning, and non-traditional education (Garrison, Schardt, \& Kochi, 2000). Numerous research reports have elaborated on the benefits associated with the use of virtual learning platforms (Goldberg \& McKhann, 2000; Piccoli, Ahmad, \& Ives, 2001). Currently, 48 states and the District of Columbia support distance/online learning (United States Department of Education, 2011). As educators from all disciplines and content areas modify their pedagogy, particularly STEM, to address their students' interests and needs, one can incorporate a myriad of interactive STEM websites into their lessons. There are numerous interactive and informative STEM websites and online scientific resources (Table 1) that are reputable to implement into a STEM curriculum, while incorporating a technology-based framework. Using a particular CBL module or multiple CBL strategies, students will have access and exposure to modern STEM advances, interactive technologies, and scientific research within their classrooms. Using reputable websites (Table 1) has the potential to increase student motivation in the scientific subject and enhance student learning by making the topic more relevant and personal. This will increase learning opportunities for students and alleviate the burden of lecturing via online, supporting student-centered learning.

Table 1: Selection of STEM websites that STEM educators can implement into their DTL pedagogy

\section{Citizen Science/Games}

Foldit

Eterna

Phylo

\section{College and Universities}

Harvard University, Personal https://pged.org/mission/

Genetics Education Project

Johns Hopkins University

Harvard University, Personal http://learn.genetics.utah.edu

Genetics Education Project

University of Utah Genetic Science Learning Center

Washington University in St. Louis https://fold.it/portal/

https://eternagame.org/

https://phylo.cs.mcgill.ca/

\section{https://learn.genetics.utah.edu/}

https://schoolpartnership.wustl.edu/instructionalmaterials/moderngenetics

\section{Museums and Nonprofit \\ Websites}

American Museum of Natural https://www.amnh.org/explore/videos History

American Society for Microbiology http://www.asm.org/index.php/in-the-classroom\#k12 


\author{
American Society of Human http://www.ashg.org/education/K12.shtml \\ Genetics \\ Dolan DNA Center (Cold Spring https://www.dnalc.org/resources/ \\ Harbor Laboratories) \\ Education Development Center \\ http://www2.edc.org/weblabs/ \\ Howard Hughes Medical Institute \\ http://www.hhmi.org/biointeractive \\ Smithsonian National Museum of https://naturalhistory.si.edu \\ Natural History
}

\title{
National Institutes of Health and other Federal Resources
}

BLAST, NCBI, NLM

https://www.ncbi.nlm.nih.gov/blast/

Gene Ed, NLM, National Human

Genome Research Institute (NHGRI)

Genetics Home Reference, NLM

Department of Energy

https://www.genome.gov/

https://ghr.nlm.nih.gov/

https://www.energy.gov/ne/information-resources/stem-resources

Online Distance Learning. While online learning has become increasingly useful at all levels of schooling, postsecondary online learning has been increasingly incorporated in college and university curricula. As shown in Table 2, enrollment exclusively in online postsecondary courses all-totaled increased by 595,026 (2,664,534 $3,259,560$ ) from 2013 to 2019. Likewise, enrollees who took some courses online, but not exclusively online, increased by $833,937(2,843,752-3,677,789)$. All-totaled, during these five years, the increase in enrollments for the combined categories of exclusively online and partially online was $1,429,013$. Although during the period of 2013 to 2019, a substantial number of students were not enrolled in online courses, there was a marked decrease during the five years $(15,339,764-13,071,185)$. In general, the data indicates that even with a notable increase in online distance learning during this half decade, there remains a large number of students' currently non-enrolled online who potentially could benefit by greater access to the affordances of various forms of distance learning.

Table 2: Postsecondary enrollments in distance learning courses 2013 to 2019

\begin{tabular}{llll}
$\begin{array}{l}\text { Year } \\
\text { range }\end{array}$ & $\begin{array}{l}\text { Encllusively in } \\
\text { exome courses, }\end{array}$ & in no online \\
online courses & not all online & \multicolumn{1}{l}{ courses } & \\
$2013-14$ & $2,664,534$ & $2,843,752$ & $15,339,764$ \\
$2014-15$ & $2,823,512$ & $2,901,022$ & $14,939,646$ \\
$2015-16$ & $2,877,188$ & $3,095,280$ & $14,427,696$ \\
$2016-17$ & $2,980,184$ & $3,330,529$ & $13,919,299$ \\
$2017-18$ & $3,104,913$ & $2,703,529$ & $13,480,913$ \\
$2018-19$ & $3,259,560$ & $3,677,689$ & $13,071,185$
\end{tabular}

Note: Derived from National Center for Education Statistics: IPEDS Data Explorer (https://nces.ed.gov/).

\section{Approaches to Distance Teaching and Learning}

STEM educators should work with the websites and online resources that they are familiar with while gradually acquiring new online STEM pedagogy. For novice STEM educators, allocating time too much time and effort to 
learn, explore, navigate, and implement online STEM and resources may steer student focus away from reassuring students their confidence with learning the topic of discussion. One of the most important factors of adjusting one's pedagogy to DTL is to realize one's strengths with a pedagogical framework. For example, many STEM educators thrive in a laboratory setting, look for websites that support CML through a laboratory lens.

Southworth et al. (2010) promote the use of a virtual laboratory environment to supplement and/or in-place-of a traditional hands-on classroom laboratory. For more than twenty years "educational technology research have demonstrated the power of cyberlearning in helping students construct rich mental models of genetics." (p. 3)

Interdisciplinary learning. Interdisciplinary learning is an excellent pedagogical strategy for learning STEM in CBL format. For example, STEM educators can prepare content material prior to class (as any professional educator should) by providing the weblink, questions for discussion, and student-centered learning activities and resources, while engaging with an online laboratory assignment or presentation. STEM educators can monitor student participation and posts, make online appointments for students with specific needs or questions, and understand how to incorporate technology into their student learning. Studies have shown that students who develop interdisciplinary skills and strategies familiarized themselves with innovative learning, design process, sharing educational and technological resources, collaborating with industry, and research (Frank \& Barzilai, 2004). The term "interdisciplinary" has been defined as a process of incorporating multiple disciplines with the intention of developing new ideas, make connections, explain a phenomenon, or solve a problem, that would be unlikely through a single disciplinary means (Tripp \& Shortlidge, 2019). Interdisciplinary learning provides more opportunities for enhancing student learning by exposing them to multiple domains of STEM that cross disciplines to solve personal and societal problems.

\section{Professional Development}

Considering the number of professional development courses, training, and academic resources that many STEM teachers have access to, and in some cases are required to fulfill, more effort is needed to make them truly transformative (Bybee 2010) when implementing interactive websites into the formal and DTL domain. Professional development for teacher education in STEM programs vary across a range of improvements such as developing expert competence in interdisciplinary teaching, enhancing student learning in STEM fields, improving student attitudes pertaining to the importance of STEM in society, and introduce real-life/real-world applications that inspire students to pursue the education necessary to participate in a career in STEM (Holmlund, Lesseig, \& Slavit, 2018; Tripp \& Shortlidge, 2019). Professional development should include more opportunities to include and implement modern, interactive websites associated with STEM. Not only does the implementation of professional development affect scientific literacy and the nature of science, it limits a student's level of scientific engagement with CBL (Darling-Hammond et al. 2020). For some STEM educators, there is no incentive to take-part in a professional development course/workshop that addresses implementing interactive STEM websites into the classroom. Perhaps it does not correlate with the existing curriculum, students are not suitable to utilizing these types of websites or learning how to utilize and implement new interactive websites may be intense and/or intimidating for some educators.

Because learning is a never-ending process, it is plausible to think that it may be overwhelming for some STEM educators to acquire new pedagogical skills and strategies to implement into their course. However, collaborating with a professional development network consistently will support the growth of an educator, school/college community and student learning. It would be beneficial if more than two STEM educators from the same institution or instructional unit attended professional development so they can gain greater benefit by encouraging each other to better understand content material, develop strategies for teaching, and improve troubleshooting skills with any challenges that may arise subsequently. Moreover, this will alleviate frustration that sometimes occur when new practices are employed on one's own. "Successful professional development should result in measurable increases in teacher knowledge and skills that are linked to outcomes in student achievement" (Kovarik et al., 2013, p. 444).

One of the challenges for many STEM educators is to enroll in consistent professional development courses that offer CBL and increase their awareness of the current paradigm shift with DTL. Further research is needed at all levels of education in order to analyze the effectiveness of CBL in STEM education. Once these factors are 
identified, it is up to the school and/or school district to effectively implement policies that promote and increase the use of these interactive websites. Overall, DTL is ever increasingly needed in all levels of education 6-12 and undergraduate, the COVID-19 pandemic has made this more apparent, if not more demanding, and educators can do better - they need more professional development, 'especially transformative' in STEM education.

\section{Limitations}

The COVID-19 pandemic, unfolding in early 2020, undoubtedly will bring many additional challenges and new insights as societies come to grips with its social, cultural, and epidemiological consequences. Hence, there are many implications likely to develop that this current article could not fully predict. Additional research of this kind is going to be needed for future educational planning and research. I have purposefully limited my search to certain educational aspects that seem most pertinent to this COVID-19 pandemic and the potential uses with online learning. There are other major themes that can be developed based on this, and other, relevant articles that may make further interpretations of the educational implications with broader societal, cultural, medical, epidemiological and psychological dimensions, among others.

\section{Conclusions}

While there continues to be speculation as to when $\mathrm{K}-12$ schools, colleges, and institutions that teach formally will likely resume, the current educational transition that has been put into place during the COVID-19 pandemic will definitely be a historical mark in education. The expansion of DTL education will further increase its presence in education while educators adjust their pedagogical skills and strategies to address student learning and assessment. McKimm, Jolie, and Cantillon (2006) suggest identifying students' needs, provide effective support by assisting learners to adapt to technology, and implementing multimedia resources into their curricula.

This educational paradigm shift will impose continued educational shifts in planning, thinking, and curriculum restructuring with DTL in all levels of education. As a result, DTL and education overall, will rapidly progress, and the domain of education will most likely change with an increased emphasis computer and technology-based learning.

\section{References}

Agarwal S, Kaushik JS. Student's Perception of Online Learning during COVID Pandemic. Indian Journal Pediatrics 2020;87(7):554. doi:10.1007/s12098-020-03327-7

Barrett, B. (2010). Virtual teaching and strategies: Transitioning from teaching traditional classes to online classes. Contemporary Issues in Education Research, 3(12), 17-20. doi:10.19030/cier.v3i12.919

Bybee RW. What is STEM Education?. Science. 2010;329(5995):996. doi:10.1126/science.1194998

Darling-Hammond, L., Flook, L., Cook-Harvey, C., Barron, B., \& Osher, D. (2020) Implications for educational practice of the science of learning and development. Applied Developmental Science, 24(2), 97-140. doi:10.1080/10888691.2018.1537791

Frank, M., \& Barzilai, A. (2004). Integrating alternative assessment in a project-based learning course for preservice science and technology teachers. Assessment \& Evaluation in Higher Education, 29(1), 41-61. doi:10.1080/0260293042000160401

Freeman, S., Eddy, S. L., McDonough, M., Smith, M. K., Okoroafor, N., Jordt, H., \& Wenderoth, M. P. (2014). Active learning increases student performance in science, engineering, and mathematics. Proceedings of the National Academy of Sciences of the

United States of America, 111(23), 8410-8415. doi:10.1073/pnas.1319030111 Garrison, J. A., Schardt, C., \& Kochi, J. K. (2000). Web-based distance continuing education: a new way of thinking for students and instructors. Bulletin of the Medical Library Association, 88(3), 211.

Goldberg HR, McKhann GM. Student test scores are improved in a virtual learning environment. Advances in Physiology Education. 2000; 23(1):59-66. doi:10.1152/advances.2000.23.1.S59 
Holmlund, T. D., Lesseig, K., \& Slavit, D. (2018). Making sense of "STEM education" in K-12 contexts. International Journal of STEM Education, 5(1), 32. doi:10.1186/s40594-018-0127-2

Kovarik, D. N., Patterson, D. G., Cohen, C., Sanders, E. A., Peterson, K. A., Porter, S. G., \& Chowning, J. T. (2013). Bioinformatics education in high school: implications for promoting science, technology, engineering, and mathematics careers. CBE Life Sciences Education, 12(3), 441-459. doi:10.1187/cbe.12-11-0193

Major C. (2020). Innovations in Teaching and Learning during a Time of Crisis. Innovative Higher Education, 1-2. Advance online publication. doi:10.1007/s10755-020-09514-w.

McKimm, J., Jollie, C., \& Cantillon, P. (2003). ABC of learning and teaching: Web based learning. British Medical Journal (Clinical research ed.), 326(7394), 870-873. doi:10.1136/bmj.326.7394.870

Nicola, M., Alsafi, Z., Sohrabi, C., Kerwan, A., Al-Jabir, A., losifidis, C., Agha, M., \& Agha, R. (2020). The socioeconomic implications of the coronavirus pandemic (COVID-19): A review. International Journal of Surgery (London, England), 78, 185-193. doi:10.1016/j.ijsu.2020.04.018

Piccoli, G., Ahmad, R., \& Ives, B. (2001). Web-Based Virtual Learning Environments: A Research Framework and a Preliminary Assessment of Effectiveness in Basic IT Skills Training. MIS Quarterly, 25(4), 401-426. doi: $10.2307 / 3250989$

Ryan, E., \& Poole, C. (2019). Impact of Virtual Learning Environment on Students' Satisfaction, Engagement, Recall, and Retention. Journal of Medical Imaging and Radiation Sciences, 50(3), 408-415. doi:10.1016/j.jmir.2019.04.005

Sahu P. (2020). Closure of Universities Due to Coronavirus Disease 2019 (COVID-19): Impact on Education and Mental Health of Students and Academic Staff. Cureus, 12(4), e7541. doi:10.7759/cureus.7541

Southworth, M., Mokros, J., Dorsey, C. \& Smith, R. (2010). The Case for Cyberlearning: Genomics (and Dragons!) in the High School Biology Classroom. Science Teacher, 77(7), 28-33. Retrieved June 30, 2020 from https://www.learntechlib.org/p/50513/.

Stipek, D. (2002). Motivation to learn: From theory to practice (4th edition). (pp. 272 pages). Needham Heights, MA: Allyn \& Bacon.

Tripp, B., \& Shortlidge, E. E. (2019). A Framework to Guide Undergraduate Education in Interdisciplinary Science. CBE life sciences education, 18(2), es3. doi:10.1187/cbe.18-11-0226

U.S. Department of Education (2011). Use of Technology in Teaching and Learning. https://www.ed.gov/oiinews/use-technology-teaching-and-learning

Table 1: Selection of STEM websites that STEM educators can implement into their DTL pedagogy.

\begin{tabular}{|l|l|}
\hline Citizen Science/Games & \\
\hline Foldit & $\underline{\text { https://fold.it/portal/ }}$ \\
\hline Eterna & $\underline{\text { https://eternagame.org/ }}$ \\
\hline Phylo & $\underline{\text { https://phylo.cs.mcgill.ca/ }}$ \\
\hline College and Universities & \\
\hline $\begin{array}{l}\text { Harvard University, Personal } \\
\text { Genetics Education Project }\end{array}$ & https://pged.org/mission/ \\
\hline Johns Hopkins University & https://www.omim.org \\
\hline $\begin{array}{l}\text { Harvard University, Personal } \\
\text { Genetics Education Project }\end{array}$ & http://learn.genetics.utah.edu \\
\hline $\begin{array}{l}\text { University of Utah Genetic Science } \\
\text { Learning Center }\end{array}$ & https://learn.genetics.utah.edu/ \\
\hline
\end{tabular}




\begin{tabular}{|c|c|}
\hline Washington University in St. Louis & $\begin{array}{l}\text { https://schoolpartnership.wustl.edu/instructionalmaterials/modern- } \\
\text { genetics }\end{array}$ \\
\hline $\begin{array}{l}\text { Museums and Nonprofit } \\
\text { Websites }\end{array}$ & \\
\hline $\begin{array}{l}\text { American Museum of Natural } \\
\text { History }\end{array}$ & https://www.amnh.org/explore/videos \\
\hline American Society for Microbiology & http://www.asm.org/index.php/in-the-classroom\#k12 \\
\hline $\begin{array}{l}\text { American Society of Human } \\
\text { Genetics }\end{array}$ & http://www.ashg.org/education/K12.shtml \\
\hline $\begin{array}{l}\text { Dolan DNA Center (Cold Spring } \\
\text { Harbor Laboratories) }\end{array}$ & https://www.dnalc.org/resources/ \\
\hline Education Development Center & http://www2.edc.org/weblabs/ \\
\hline Howard Hughes Medical Institute & http://www.hhmi.org/biointeractive \\
\hline $\begin{array}{l}\text { Smithsonian National Museum of } \\
\text { Natural History }\end{array}$ & https://naturalhistory.si.edu \\
\hline \multicolumn{2}{|l|}{$\begin{array}{l}\text { National Institutes of Health and } \\
\text { other Federal Resources }\end{array}$} \\
\hline BLAST, NCBI, NLM & https://www.ncbi.nlm.nih.gov/blast/ \\
\hline $\begin{array}{l}\text { Gene Ed, NLM, National Human } \\
\text { Genome Research Institute (NHGRI) }\end{array}$ & https://www.genome.gov/ \\
\hline Genetics Home Reference, NLM & https://ghr.nlm.nih.gov/ \\
\hline Department of Energy & https://www.energy.gov/ne/information-resources/stem-resources \\
\hline
\end{tabular}

Table 2: Postsecondary enrollments in distance learning courses 2013 to 2019

\begin{tabular}{llll}
\hline $\begin{array}{l}\text { Year } \\
\text { range }\end{array}$ & $\begin{array}{l}\text { Enrollment } \\
\text { exclusively in } \\
\text { online courses }\end{array}$ & $\begin{array}{l}\text { Enrollment in } \\
\text { some courses, } \\
\text { not all online }\end{array}$ & $\begin{array}{l}\text { Enrollment } \\
\text { in no online } \\
\text { courses }\end{array}$ \\
$2013-14$ & $2,664,534$ & $2,843,752$ & $15,339,764$ \\
$2014-15$ & $2,823,512$ & $2,901,022$ & $14,939,646$ \\
$2015-16$ & $2,877,188$ & $3,095,280$ & $14,427,696$ \\
$2016-17$ & $2,980,184$ & $3,330,529$ & $13,919,299$ \\
$2017-18$ & $3,104,913$ & $2,703,529$ & $13,480,913$ \\
$2018-19$ & $3,259,560$ & $3,677,689$ & $13,071,185$
\end{tabular}

